\title{
E R R ATA
}

\section{nature}

\section{neuroscience}

\section{Erratum: Functional dissection of circuitry in a neural integrator}

Emre Aksay, Itsaso Olasagasti, Brett D Mensh, Robert Baker, Mark S Goldman \& David W Tank

Nat. Neurosci. 10, 494-504 (2007); published online: 18 March 2007; corrected after print 2 May 2007

In the version of this article initially published, the labels for the $x$-axes in Figure 8, panels $\mathbf{c}$ and $\mathbf{d}$ were incorrect. The correct labels should be "Rate, left". This error has been corrected in the HTML and PDF versions of the article.

\section{Erratum: Channel, neuronal and clinical function in sodium} channelopathies: from genotype to phenotype

\section{Stephen G Waxman}

Nat. Neurosci. 10, 405-409 (2007); published online 27 March 2007; corrected after print 25 May 2007

In the version of this article initially published, the online publication date was incorrectly given as 25 February 2007 . The correct date is 27 March 2007. This error has been corrected in the PDF version of the article. 